\title{
Effect of Dextrinized Sweet potatoes on the Physicochemical and Sensory Quality of Infra-Red Dried Mango Leather
}

\author{
Effah-Manu L ${ }^{1 *}$, Oduro I ${ }^{1}$ and Addo $A^{2}$
}

${ }^{1}$ Department of Food Science and Technology, Kwame Nkrumah University of Science and Technology, PMB, University Post Office, Kumasi, Ghana ${ }^{2}$ Department of Agricultural Engineering, Kwame Nkrumah University of Science and Technology, PMB, University Post Office, Kumasi, Ghana

\begin{abstract}
Dextrinization of sweet potato and its effect on physicochemical and sensory quality of mango-sweet potato leathers was studied. Sweet potatoes were dextrinized in an oven at different temperatures $\left(150-200^{\circ} \mathrm{C}\right)$ and time $(2,2.5$ and $3.0 \mathrm{~h})$ for optimization using completely randomized design. Maximum dextrin of 19.41 was formed at $190-200^{\circ} \mathrm{C}$. Water activity and $\mathrm{pH}$ ranged from $0.61-0.63$ and $4.2-4.33$ respectively and vitamin $\mathrm{C}$ increased with the addition of sweet potato. The overall acceptability was high $(1.58-1.63)$ but non-significant $(p<0.05)$ with the amount of sweet potato added. The mouth feel was disliked slightly (4.06-4.40) by panellists but colour, smell and taste were rated high (1.00-0.97). Dextrinization of sweet potatoes could be considered as an excellent substitute in food applications like fruit leathers production and hence provide alternative products for health conscious consumers.
\end{abstract}

Keywords: Dextrinization; Mango; Physico chemical; Postharvest; Sensory; Sweet potatoes

\section{Introduction}

Mangoes (Magnifera indica L, keitt variety) are produced in considerable quantities and consumed locally, but are seldom processed. Alzamora et al. [1] reported that about $30-50 \%$ of fruits and vegetables in developing countries like Ghana are never consumed due to losses during storage and transportation. Mangoes (Magnifera indica) have shelf life of 3 to 4 weeks in good condition at low temperature of 10$12^{\circ} \mathrm{C}$. Nonetheless, World trade in fresh mango fruit is restricted by the highly perishable nature $[2,3]$ and as such reduces availability and increases per unit cost of transport and marketing [4]. Therefore without processing, the losses will even rise with increased production rates.

The sweet potato (Ipomoea batatas L.) is also an important source of carbohydrate, taking the fourth place after rice, corn, and cassava. Generally, the tubers are consumed in fresh form, cooked by frying or boiling and can also be used as a raw material for the feed industry [5]. Nutritionally it contains beta carotene, vitamin C, niacin, riboflavin, thiamin, and minerals [6]. Extended shelf life for sweet potatoes can be obtained when dextrinized and added to mangoes in the production of fruit leathers. This will also increase the market visibility of sweet potatoes.

Dextrinization, also known as pyroconversion, refers to partial depolymerization achieved through hydrolysis and recombination in a branched manner. Dextrinizing sweet potatoes through baking causes hydrolysis of starch by endogenous enzymes into maltose [7] and longer chain polysaccharides. The extent of hydrolysis is normally expressed in terms of the "dextrose equivalent" (DE), which is the measure of the total reducing power of the sugars present relative to a dextrose (D-glucose) standard, on a dry mass basis. In the dextrinized form, the sweet potato can be useful as binding and "sweetening" agent [8] in fruit leather production.

Fruit leathers are made by drying fruit puree or a mixture of fruit juice concentrate and other ingredients on a flat surface in an oven or in direct sunlight [9-11]. In the preparation of fruit leathers, additives such as starch, high fructose corn syrups and sugar are used [12]. According to Xuguang and Fu-Hung [13], these additives are known to cause deterioration of quality parameters during storage and increase caloric content of leathers. To meet the needs of health conscious consumers, it has become necessary to introduce dextrinized sweetpotoes which is "natural" into the production of fruit leathers.

Hence the objective of this work was to determine the extent of sweet potato starch dextrinization and its effect on the physicochemical and organoleptic quality characteristics of infra-red dried fruit leathers.

\section{Practical applications}

Although mangoes can be used during different stages of growth, maturity and ripening by processing industries in Ghana, export of fresh mangoes is continuously increasing. The Export Development and Investment Fund aimed at supporting farmer-based organizations to facilitate the cultivation of mango for export across four regions in the country could be channelled into producing fruit leathers. Making fruit leathers from mangoes and sweet potatoes would reduce the export weight and increase export returns than when whole mangoes are exported. The result of the study on manufacturing of mango-sweet potato leather will improve on the marketability of mango and sweet potato which will improve the financial status of farmers. Nutritionally, children and adults alike will have access to instant energy. Health conscious individuals will have a choice for low calories snack like mango-sweet potato leather.

\section{Materials and Methods}

\section{Sample preparation}

Freshly harvested mangoes (Keitt variety) were obtained from the

${ }^{*}$ Corresponding author: L. Effah-Manu, Department of Food Science and Technology, Kwame Nkrumah University of Science and Technology, PMB, University Post Office, Kumasi, Ghana, Tel: +233 206411628; E-mail effahmanuliticia@yahoo.com

Received March 21, 2013; Accepted April 18, 2013; Published April 25, 2013

Citation: Effah-Manu L, Oduro I, Addo A (2013) Effect of Dextrinized Sweet potatoes on the Physicochemical and Sensory Quality of Infra-Red Dried Mango Leather. J Food Process Technol 4: 230. doi:10.4172/2157-7110.1000230

Copyright: @ 2013 Effah-Manu L, et al. This is an open-access article distributed under the terms of the Creative Commons Attribution License, which permits unrestricted use, distribution, and reproduction in any medium, provided the original author and source are credited. 
Faculty of Agriculture, KNUST and sweet potatoes (Faraa variety) from the Kumasi Central Market. Sweet potatoes were wrapped in black polythene bags and exposed to the sun with mean solar irradiance of $413.75 \mathrm{~W} / \mathrm{m}^{2}$ [14]. The sweet potato $(2 \mathrm{~kg})$ was baked in an oven for $2 \mathrm{~h}, 2.5 \mathrm{~h}$ and $3 \mathrm{~h}$ at $150-220^{\circ} \mathrm{C}$ to convert the starch to dextrins. The edible portion was scooped after cooling to $30^{\circ} \mathrm{C}$ and homogenized in an electric blender (Philips Co. Ltd. Model HR2021). Fully ripe mangoes $(1 \mathrm{~kg})$ were washed, peeled and manually cut into pieces with a knife. The sample was pureed with 1tablespoonful $(2 \mathrm{ml})$ of lemon juice, $0.1 \%$ sodium benzoate and $0.2 \%$ citric acid at low speed using a blender (Philips Co. Ltd. Model HR2021). Afterwards, it was poured into a stainless steel container and placed in a water bath at $80^{\circ} \mathrm{C}$ for 30 min to deactivate the enzymes.

\section{Development of mango-sweet potato leather}

The mango puree and the sweet potato slurry were mixed in the following ratio: 70:30 g, 80:20 $\mathrm{g}$ and 90:10 $\mathrm{g}$ were added respectively to obtain a homogenous mixture of $100 \mathrm{~g}$. The mixture was then poured into aluminum trays of $7 \mathrm{~mm} \times 7 \mathrm{~mm}$ which had previously been washed, dried and coated with glycerol. Drying was done in triplicates in a Bruest Flameless Gas Infrared Catalytic Heater (Catalytic Industrial Group, model SR-12) at $45^{\circ} \mathrm{C}, 50^{\circ} \mathrm{C}$ and $55^{\circ} \mathrm{C}$. However, physico-chemical analyses were conducted on leathers dried at $50^{\circ} \mathrm{C}$ due to energy considerations. The leathers were rolled in an $\mathrm{Al}$ foil and packaged in cellophane film for analyses.

\section{Dextrins determination}

Dextrins were determined as material insoluble in $80 \%(\mathrm{v} / \mathrm{v})$ ethanol. Alcohol insoluble solids were measured on 25g samples of slurry extracted twice with $100 \mathrm{ml}$ of hot $80 \%$ ethanol in water bath at $65^{\circ} \mathrm{C}$. The sample was left overnight and alcohol decanted followed by drying of the residue at $95^{\circ} \mathrm{C}$ in an oven according to the methods used by Walter, Purcell and Walter $[15,16]$. The percentage dextrinization (Dex) of starch was calculated as:

$$
\% \text { Dex }=\frac{\text { Weight of material insoluble in alcohol }}{\text { Weight of fresh sample }} \times 100
$$

\section{Determination of total soluble solids ( ${ }^{\circ}$ Brix)}

Total soluble solids were determined using the analogue hand held refractometer (Atago Co. Ltd. Model Master-Pa,) with accuracy of Brix $\pm 0.2 \%\left(10\right.$ to $\left.30^{\circ} \mathrm{C}\right)$. Distilled water and test solution of known sucrose concentration was used to calibrate the instrument. Readings were done in duplicates and averaged for analysis.

\section{Determination of dextrin's DE-value}

To $1 \mathrm{~g}$ of slurry, $50 \mathrm{ml}$ distilled water was added and filtered. An aliquot of the filtrate was transferred to a tube containing $0.5 \mathrm{ml}$ of 3,5-dinitrosalicylic acid to measure the content of reducing sugar with glucose as standard $[16,17]$. DE value was calculated using the equation

$$
D E(\%)=\frac{\text { Reducing sugar content }(\text { glu } \cos e)}{\text { Total solids content }} \times 100
$$

\section{Proximate analysis}

The proximate analysis on the fresh and dried samples was conducted on wet basis at the Department of Biochemistry and Biotechnology Laboratory at the Kwame Nkrumah University of Science and Technology. The moisture content, crude protein, crude fat, crude fibre, carbohydrate and ash were determined according to AOAC methods [18].

\section{Determination of vitamin C (total ascorbic acid) content}

Metaphosphoric acid-acetic acid solution $(5 \mathrm{ml})$ was pipetted and added to $2 \mathrm{ml}$ ascorbic acid standard solution in Erlenmeyer flasks in triplicates. Blanks as well as the sample $(2 \mathrm{ml})$ were prepared from indophenol dye solution titrated against the standard ascorbic solution in the flask until a distinct rose-pink colour formed and persisted for more than 5s. This was done in triplicates and the initial and final readings of the burette was taken and used to calculate the average titre of dye used [19].

\section{Measurement of colour}

Fully dried leathers were evaluated for color using the chromameter (Minolta Co. Ltd., model CR 310) at the Food Research Institute laboratory in Accra. The chromameter was calibrated using a white tile which gave $\mathrm{L}^{*}=76.5, \mathrm{~b}^{*}=3.23$ and $\mathrm{a}=5.45$ as standards. Six measurements were performed on each sample at different positions and the mean values used.

\section{Sensory evaluation procedure}

Sensory evaluation was conducted using 50 untrained panelists recruited from within and around the Kwame Nkrumah University of Science and Technology campus. The panelists were introduced to the sample and individual five point hedonic rating scale for four attributes viz., colour, aroma, taste and overall acceptability. They were allowed to chew samples, as each desired and rinse the mouth with water inbetween tasting. Panellists scored using a five point hedonic scale, in which 1: represented like very much, 2: like slightly, 3: neither like nor dislike, 4 : dislike slightly and 5: dislike very much.

\section{Results and Discussion}

\section{Dextrin and dextrose equivalent (DE) values determination}

The DE of sweet potatoes before curing was found to be 10.32 with no dextrins and after curing this value increased to 11.86. According to Nabubuya et al. [20] curing and storing sweet potatoes at ambient conditions generally register the highest amylase activity. Further findings reported by other researchers show that curing under direct sunlight $\left(28-30^{\circ} \mathrm{C}, 85-90 \%\right.$ relative humidity) increase amylolytic activity $[21,22]$. This explains the increases in DE observed after curing sweet potatoes.

Dextrins, which are made up of mixtures of polymers of D-glucose units linked by $1 \alpha \rightarrow 4$ or $1 \alpha \rightarrow 6$ glycosidic bonds are formed during hydrolysis of starch. The results of the amount of dextrin formed and dextrose equivalent (DE) are presented in table 1. Generally, dextrin formation was affected significantly $(\mathrm{p}<0.5)$ by temperature and time of baking. From table 1, dextrin formation increased at all temperature ranges except for $200-210^{\circ} \mathrm{C}$ and $210-220^{\circ} \mathrm{C}$ where dextrin formation was found to decrease with increased time of roasting. Dextrin and dextrose equivalent values were optimal (32.91 and 19.49 respectively) at $190-200^{\circ} \mathrm{C}$. However no significant differences $(\mathrm{p}<0.05)$ were found for $\mathrm{DE}$ values within the temperature range of $200-220^{\circ} \mathrm{C}$. Optimum $\mathrm{DE}$ values were obtained at $190-200^{\circ} \mathrm{C}$. This result is quite similar to earlier research by Walter [16] who found that the optimum temperature for dextrinizing sweet potato starch through roasting is $191^{\circ} \mathrm{C}$ for $2.5 \mathrm{~h}$. Baking temperatures above $200^{\circ} \mathrm{C}$ resulted in burnt outer skin of roots and partial cooking of inner portions. This was associated with water leaching from tubers. This leaching, according to literature is accompanied with soluble amylose which resulted in cohesiveness of such tubers Alais and Linden, Hoover, Moorthy [23-25]. 


\begin{tabular}{|c|c|c|c|}
\hline Temperature $\left({ }^{\circ} \mathrm{C}\right)$ & Time (h) & Dextrins (\%) & Dextrose equivalent \\
\hline $150-160$ & $\begin{array}{l}2.0 \\
2.5 \\
3.0\end{array}$ & $\begin{array}{l}15.96 \pm 0.5^{\mathrm{a}} \\
16.34 \pm 0.2^{\mathrm{b}} \\
16.22 \pm 1.6^{\mathrm{c}}\end{array}$ & $\begin{array}{l}14.21 \pm 0.2^{\mathrm{a}} \\
14.05 \pm 0.2^{\mathrm{a}} \\
14.52 \pm 0.5^{\mathrm{b}}\end{array}$ \\
\hline $160-170$ & $\begin{array}{l}2.0 \\
2.5 \\
3.0\end{array}$ & $\begin{array}{l}14.45 \pm 2.0^{\mathrm{a}} \\
17.38 \pm 0.7^{\mathrm{b}} \\
18.00 \pm 1.3^{\mathrm{c}}\end{array}$ & $\begin{array}{l}14.57 \pm 0.4^{\mathrm{a}} \\
14.60 \pm 0.1^{\mathrm{a}} \\
14.81 \pm 0.8^{\mathrm{b}}\end{array}$ \\
\hline $170-180$ & $\begin{array}{c}2 \\
2.5 \\
3.0\end{array}$ & $\begin{array}{l}16.97 \pm 0.9^{\mathrm{a}} \\
18.43 \pm 0.2^{\mathrm{b}} \\
20.65 \pm 2.1^{\mathrm{c}}\end{array}$ & $\begin{array}{l}15.50 \pm 0.6^{\mathrm{a}} \\
15.78 \pm 0.4^{\mathrm{b}} \\
15.80 \pm 0.1^{\mathrm{b}}\end{array}$ \\
\hline $180-190$ & $\begin{array}{c}2 \\
2.5 \\
3.0\end{array}$ & $\begin{array}{l}19.45 \pm 0.4^{\mathrm{a}} \\
21.67 \pm 1.7^{\mathrm{b}} \\
23.23 \pm 2.5^{\mathrm{c}}\end{array}$ & $\begin{array}{l}17.77 \pm 0.3^{\mathrm{b}} \\
17.54 \pm 0.7^{\mathrm{a}} \\
17.89 \pm 0.4^{\mathrm{b}}\end{array}$ \\
\hline $190-200$ & $\begin{array}{l}2.0 \\
2.5 \\
3.0\end{array}$ & $\begin{array}{l}32.89 \pm 0.3^{\mathrm{a}} \\
32.91 \pm 0.8^{\mathrm{a}} \\
32.90 \pm 0.4^{\mathrm{a}}\end{array}$ & $\begin{array}{l}19.08 \pm 0.2^{\mathrm{a}} \\
19.49 \pm 0.7^{\mathrm{b}} \\
19.56 \pm 0.5^{\mathrm{b}}\end{array}$ \\
\hline $200-210$ & $\begin{array}{l}2.0 \\
2.5 \\
3.0\end{array}$ & $\begin{array}{l}30.50 \pm 2.8^{\mathrm{b}} \\
30.01 \pm 0.3^{\mathrm{a}} \\
27.80 \pm 0.9^{\mathrm{c}}\end{array}$ & $\begin{array}{l}19.00 \pm 0.3^{\mathrm{a}} \\
19.43 \pm 0.3^{\mathrm{b}} \\
19.20 \pm 0.8^{\mathrm{a}}\end{array}$ \\
\hline $210-220$ & $\begin{array}{l}2.0 \\
2.5 \\
3.0\end{array}$ & $\begin{array}{l}27.83 \pm 2.1^{\mathrm{c}} \\
27.29 \pm 1.8^{\mathrm{b}} \\
27.00 \pm 0.9^{\mathrm{a}}\end{array}$ & $\begin{array}{l}19.30 \pm 0.3^{\mathrm{a}} \\
18.06 \pm 0.1^{\mathrm{a}} \\
19.22 \pm 0.1^{\mathrm{a}}\end{array}$ \\
\hline
\end{tabular}

Means in the same column followed by the same letter are not significantly different from each other at $p<0.05$

Table 1: Effect of temperature and time on dextrin formation and dextrose equivalent values of baked roots.

The DE values obtained in table 1 indicate that maltodextrins were formed [26]. Maltodextrin is classified as a complex carbohydrate, but acts like a simple carbohydrate in the body [27]. This suggests that mango-sweet potato leathers will provide immediate source of energy to consumers.

\section{Physicochemical parameters of infra-red dried leathers}

Infra-red dried leathers were evaluated for $\mathrm{pH}$, acidity, water activity, colour and vitamin $\mathrm{C}$ content and the results represented in tables 2 and 3. Water activity values were within the range of $0.61-0.63$. Water activity affects the shelf life, safety, texture, flavour, and smell of foods and is a key factor in microbial growth [28]. The minimum water activity required for microbial growth is 0.60 [29] and the values obtained in this study are non-significant $(p<0.05)$ from this value. This suggests that leathers produced by infra-red catalytic dryer in this study will not allow bacterial growth but may have mould or yeast growth with increased storage period (Table 4).

The $\mathrm{pH}$ of the leathers ranged from 4.20-4.33 but was nonsignificant $(\mathrm{p}<0.05)$. An increase in $\mathrm{pH}$ was recorded for all the samples with increase in sweet potato substitution. This shows that the $\mathrm{pH}$ of the sweet potato mash (Table 5) influenced the overall $\mathrm{pH}$ of the mixture with differing amounts of the mash. The acidity values ranged from 0.37 and 0.44 as observed in table 2 . Several shelf stable fruit leathers have been reported in literature with similar values for $\mathrm{pH}$ and acidity. These include, guava; $\mathrm{pH}, 3.57-3.98$ and acidity, 0.42-0.48 [30, 31] and mango with $\mathrm{pH}$ value of 3.8 and acidity of $0.3-0.75$ [32].

The vitamin C content of leathers with $30 \%$ sweet potato (444) was found to be significantly different from only mango, $10 \%$ and $20 \%$ sweet potato $(\mathrm{p}>0.05)$. This indicates that sweet potatoes, with vitamin $\mathrm{C}$ value of $8.3 \pm 1.7 \mathrm{mg} / 100 \mathrm{~g}$ (Table 5 ) increased the vitamin $\mathrm{C}$ content of the leather. Comparatively, the difference in initial and final contents of vitamin C (initial: $25.6 \pm 2.5 \mathrm{mg} / 100 \mathrm{~g}$, final: $17.49 \pm 0.90 \mathrm{mg} / 100 \mathrm{~g}$ ) content in leathers is lower than other values recorded for banana [30] using sun drying and pawpaw and guava leathers using the oven dryer [33]. This shows that the shorter drying time that accompanies infrared drying results in high vitamin $\mathrm{C}$ retention in leathers.
The $L^{*}$ values obtained for leathers in table 2 were not significant at $\mathrm{p}<0.05$. Comparing these values to the standard $(\mathrm{L}=76.5, \mathrm{~b}=3.23$, $a=5.45)$, the $L^{*}$ values decreased slightly $(59.01-61.88), b^{*}$ values increased drastically (38.98-47.08) and $a^{\star}$ values increased by a factor of about 2. This shows that the leathers had a bright yellow colour which is in conformity with the values reported in literature [34,35]. In general, the values obtained indicate that the leathers are of quality in terms of vitamin $\mathrm{C}$ content, colour (yellowness) and water activity.

\section{Consumer affective testing on mango-sweet potato leathers}

From Table 4, the colour of the fruit leather was not significant $(\mathrm{P}<0.05)$. Incorporation of $10-30 \%$ sweet potato did not have much effect on colour as was indicated by respondents (Table 4; Plate 1). On average, the colour of the fruit leather with 10,20 and 30\% dextrinized sweet potato was liked very much by all respondents. Higher values (4.06-4.40) recorded for mouth feel indicates panelists disliked slightly. This is because, most panelists commented it was their first time taking

\begin{tabular}{|c|c|c|c|}
\hline \multirow{2}{*}{ Sample code } & \multicolumn{3}{|c|}{ Colour } \\
\cline { 2 - 4 } & $\mathbf{L}^{\mathbf{*}}$ & $\mathbf{a}^{\mathbf{*}}$ & $\mathbf{b}^{\mathbf{*}}$ \\
\hline 444 & $61.88^{\mathrm{b}} \pm 0.17$ & $12.99^{\mathrm{a}} \pm 0.03$ & $38.98^{\mathrm{a}} \pm 0.42$ \\
\hline 908 & $61.08^{\mathrm{b}} \pm 0.09$ & $13.66^{\mathrm{a}} \pm 0.08$ & $43.97^{\mathrm{b}} \pm 0.23$ \\
\hline 648 & $59.37^{\mathrm{a}} \pm 0.10$ & $14.90^{\mathrm{b}} \pm 0.12$ & $44.08^{\mathrm{b}} \pm 0.19$ \\
\hline 183 & $59.01^{\mathrm{a}} \pm 0.56$ & $14.08^{\mathrm{a}} \pm 0.10$ & $47.77^{\mathrm{c}} \pm 0.35$ \\
\hline
\end{tabular}

L: lightness, a: redness, b: yellowness Standard $(L=76.5, b=3.23, a=5.45)$.

Table 2: Colour parameters of mango and mango-sweet potato leathers.

\begin{tabular}{|c|c|c|c|c|}
\hline $\begin{array}{c}\text { Sample } \\
\text { code }\end{array}$ & $\mathbf{p H}$ & Water activity & Acidity (g/100g) & Vitamin C (mg/100g) \\
\hline 444 & $4.20 \pm 2.8^{\mathrm{a}}$ & $0.61 \pm 3.8^{\mathrm{a}}$ & $0.37 \pm 5.20^{\mathrm{a}}$ & $17.49 \pm 2.11^{\mathrm{b}}$ \\
\hline 908 & $4.32 \pm 0.2^{\mathrm{a}}$ & $0.62 \pm 4.2^{\mathrm{a}}$ & $0.40 \pm 0.55^{\mathrm{a}}$ & $16.60 \pm 0.72^{\mathrm{a}}$ \\
\hline 648 & $4.30 \pm 0.4^{\mathrm{a}}$ & $0.63 \pm 3.9^{\mathrm{b}}$ & $0.44 \pm 0.53^{\mathrm{a}}$ & $16.58 \pm 1.34^{\mathrm{a}}$ \\
\hline 183 & $4.33 \pm 0.3^{\mathrm{a}}$ & $0.61 \pm 3.0^{\mathrm{a}}$ & $0.42 \pm 0.72^{\mathrm{a}}$ & $16.00 \pm 0.90^{\mathrm{a}}$ \\
\hline
\end{tabular}

Values in the same column followed by the same letter are not significantly differen (Turkey; $p<0.05$ ). 183: only mango; 908 : Mango $+10 \%$ SP; 648 : mango $+20 \%$ SP; 444: mango + $30 \%$ SP

Table 3: Physicochemical stability of mango and mango-sweet potato (sp) leathers

\begin{tabular}{|c|c|c|c|c|c|}
\hline Sample code & \multicolumn{5}{|c|}{ Sensory attribute } \\
\hline & Colour & Mouthfeel & Taste & Smell & Overall acceptability \\
\hline 908 & $1.00^{\mathrm{a}}$ & $4.44^{\mathrm{b}}$ & $1.97^{\mathrm{a}}$ & $1.72^{\mathrm{b}}$ & $1.58^{\mathrm{a}}$ \\
\hline 648 & $1.20^{\mathrm{a}}$ & $4.06^{\mathrm{a}}$ & $1.90^{\mathrm{a}}$ & $1.59^{\mathrm{a}}$ & $1.52^{\mathrm{a}}$ \\
\hline 183 & $1.30^{\mathrm{a}}$ & $3.95^{\mathrm{a}}$ & $1.00^{\mathrm{a}}$ & $1.84^{\mathrm{b}}$ & $1.67^{\mathrm{a}}$ \\
\hline 444 & $1.00^{\mathrm{a}}$ & $4.24^{\mathrm{b}}$ & $1.67^{\mathrm{b}}$ & $1.55^{\mathrm{a}}$ & $1.63^{\mathrm{a}}$ \\
\hline
\end{tabular}

Values in the same column followed by the same letter are not significantly different (Tukey; $p<0.05$ ). 183: only mango; 908 : Mango $+10 \%$ SP; 648 : mango $+20 \%$ SP; 444: mango + $30 \%$ SP

Table 4: Effect of dextrinized sweet potato on sensory qualities of leather.
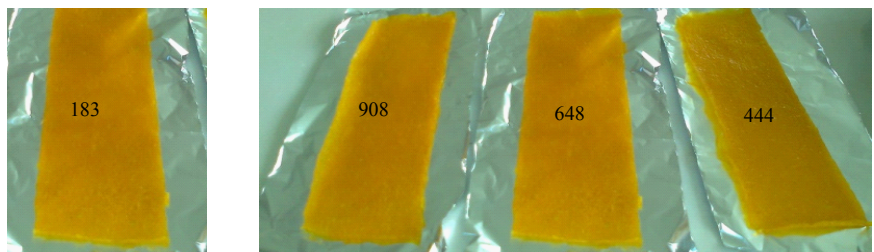

183: only mango; 908 : mango+10\%SP; 648 : mango+20\%SP; 444 mango $+30 \%$ SP

Plate 1: Mango and mango-sweetpotato leathers. 
Citation: Effah-Manu L, Oduro I, Addo A (2013) Effect of Dextrinized Sweet potatoes on the Physicochemical and Sensory Quality of Infra-Red Dried Mango Leather. J Food Process Technol 4: 230. doi:10.4172/2157-7110.1000230

Page 4 of 5

\begin{tabular}{|c|c|c|c|c|c|c|c|c|c|}
\hline \multirow[b]{2}{*}{ Percent SP } & $\mathrm{pH}$ & \multicolumn{2}{|c|}{ TSS ( ${ }^{\circ}$ Brix) } & Acidity & Vitamin C (mg /100 g) & \multirow[t]{2}{*}{ Protein (\%) } & \multirow[t]{2}{*}{ Fibre (\%) } & \multirow[t]{2}{*}{ Ash (\%) } & \multirow[t]{2}{*}{ Moisture (\%) } \\
\hline & 20 & $\begin{array}{l}10 \\
30\end{array}$ & 20 & 20 & 30 & & & & \\
\hline MSP & $\begin{array}{l}4.3 \pm 2.1 \quad 4.4 \pm 0.7 \\
4.6 \pm 0.3\end{array}$ & $\begin{array}{l}18.2 \pm 1.2 \\
23.1 \pm 0.8\end{array}$ & $20.0 \pm 3.1$ & $\begin{array}{l}0.4 \pm 0.8 \quad 0.44 \pm 0.4 \\
0.43 \pm 2.0\end{array}$ & $\begin{array}{l}17.52 \pm 3.217 .94 \pm 2.9 \\
18.08 \pm 3.6\end{array}$ & & & & \\
\hline MP & $4.2 \pm 0.1$ & $15.5 \pm 1.0$ & & $0.37 \pm 1.8$ & $17.3 \pm 2.5$ & $0.62 \pm 0.3$ & $0.33 \pm 0.2$ & $\begin{array}{l}0.38 \pm \\
0.2\end{array}$ & $88.32 \pm 0.6$ \\
\hline SP (Fresh) & $6.4 \pm 0.1$ & $9.3 \pm 2.2$ & & $0.39 \pm 0.3$ & $8.3 \pm 1.7$ & $0.78 \pm 0.2$ & $0.44 \pm 2.0$ & $\begin{array}{l}0.41 \pm \\
0.9\end{array}$ & $62.67 \pm 1.1$ \\
\hline SP (Baked) & $6.4 \pm 0.2$ & 17.6 & & $0.39 \pm 0.6$ & $5.5 \pm 0.6$ & $0.77 \pm 2.7$ & $0.44 \pm 1.3$ & $\begin{array}{l}0.40 \pm \\
0.5\end{array}$ & $48.42 \pm 0.4$ \\
\hline
\end{tabular}

MP: mango pulp, MSP: mango-sweet potato pulp, SP: sweet potato pulp.

Table 5: Physico-chemical properties of fresh mango, baked sweet potato and sweet potato pulp.

\begin{tabular}{|c|c|c|}
\hline Parameter & Mango-sweet potato leather \\
\hline Moisture (\%) & $15.4 \pm 1.2$ & Mango-leather \\
Crude protein (\%) & $2.30 \pm 0.5$ & $15.0 \pm 1.60$ \\
Crude fat (\%) & $0.38 \pm 2.0$ & $2.25 \pm 0.92$ \\
Crude fibre (\%) & $3.06 \pm 0.4$ & $0.55 \pm 0.03$ \\
Ash (\%) & $2.83 \pm 0.2$ & $2.82 \pm 0.04$ \\
Carbohydrate (\%) & $76.03 \pm 0.3$ & $2.06 \pm 0.25$ \\
\hline
\end{tabular}

Table 6: Proximate composition of mango and mango-sweet potato leathers

this type of snack hence, were not used to the chewy nature of the leathers. The low sugar content of the leathers could be a factor since it is known to increase leather chewiness, [31]. Nevertheless, respondents stated that the sugar content was alright. The taste recorded values from 1.00 to 1.67 which represent like very much to like slightly.

The overall acceptability (1.58-1.63) of mango fruit leather was not significantly affected $(\mathrm{P}<0.05)$. This shows that $30 \%$ dextrinized sweet potato can be used in mango leathers production without consumers detecting any change when compared with leathers made from mangoes only. General comments by panellists indicated that laboratory made mango-sweet potato leather was "aesthetically appealing (Plate 1), very fruity, and sweet".

It will therefore be prudent for fruit leather producers to use cured and dextrinized sweet potatoes especially in low income countries like Ghana since it has the potential for competing with commercial leathers when properly packaged.

\section{Proximate composition of leathers}

Foods show extended variability in composition (mainly water, proteins, carbohydrates, fat, ash, and fibre) and structure, and can be turned into even more complex composite materials when heated [36] as in the case of mango-sweet potato leather. In table 5 some physico-chemical parameters of the raw materials have been outlined. Proximate analysis was carried out on the leather with $30 \%$ sweet potato after sensory analysis to ascertain its moisture, protein, crude fat, crude fibre, ash and carbohydrate composition (Table 6).

The moisture content of mango-sweet potato leather (15.4\%) was lower than that recorded for guava and mango leathers; $18.47 \%$ and $2.10 \%$ respectively as reported by Ashaye et al. [33]. Additionally, moisture of jackfruit leathers dried in the cabinet, oven and solar dryers respectively had moisture contents of $18.85 \%, 14.79 \%$ and $18.5 \%$ [37]. Comparison of these results to value obtained in this work shows the effectiveness of the infra-red dryer in dehydration.

The protein content of the baked sweet potato (Table 5) could be the reason for the rise in protein content of the mango-sweet potato leather (Table 6) although the increase was not significant at $\mathrm{p}<0.05$. The disparity in literature values of crude protein content of sweet potatoes $(0.71-0.09 \%)$ [38] could result from the variety, the growth conditions and experimental setting.

The increase in crude fibre in leathers may be attributed to the contribution of fibre from the sweet potato (Table 5). The amount of fibre in the sweet potato used was higher (0.44) than literature values $(0.12-0.14 \%)$ [38], $(2.01-3.87 \mathrm{~g} / 100 \mathrm{~g})$ [39]. Crude fibre is a measure of the quantity of indigestible cellulose, pentosans, lignin, and other components of this type in processed foods. These components provide the bulk necessary for proper peristaltic action in the intestinal tract. Hence higher value for crude fibre in mango-sweet potato leather is expected to contribute to proper leather digestion.

The ash content ranged from $0.26-0.28 \%$ and no trend was observed for the various temperature ranges. This implies that temperature and the percentage of sweet potato had no effect on the ash content of leathers. The ash content is a measure of the total amount of minerals present within a food. High mineral contents are sometimes used to retard the growth of certain microorganisms and can have beneficial effects on the physicochemical properties of foods.

Overall, the initial proximate values of the raw samples had influence on the final values of the dried leathers and can be inferred that the quality of the raw material cannot be improved during and/or after processing.

\section{Conclusion}

Starch in sweet potato is dextrinized at $190-200^{\circ} \mathrm{C}$ for $2.5 \mathrm{~h}$. Baking at temperatures above $200^{\circ} \mathrm{C}$ resulted in leaching of amylose along with its natural moisture which leads to a reduction in dextrin formation. Water activity and $\mathrm{pH}$ ranged from $0.61-0.63$ and $4.2-4.33$ respectively and vitamin $\mathrm{C}$ increased with the addition of sweet potato. The overall acceptability of mango-sweet potato leather was high (1.58-1.63) but not significant $(\mathrm{P}<0.05)$ by the amount of sweet potato added. This research has shown that improvement of native sweet potato can be achieved through dextrinization and hence could be considered as an excellent alternative in food applications like in fruit leathers production.

\section{Acknowledgements}

The authors are grateful for the support provided for this research by the Staffs 
Citation: Effah-Manu L, Oduro I, Addo A (2013) Effect of Dextrinized Sweet potatoes on the Physicochemical and Sensory Quality of Infra-Red Dried Mango Leather. J Food Process Technol 4: 230. doi:10.4172/2157-7110.1000230

of the Biochemistry and Biotechnology Laboratory and Lecturers at the Department of Food Science and Technology, Kwame Nkrumah University of Science and Technology.

\section{References}

1. Alzamora SM, Tapia MS, Lo'Pez-Malo A (2000) Minimally Processed Fruits and Vegetables: Fundamental Aspects and Applications. Pp: 1-62, Gaithersburg, MD: Aspen Publishers Inc.

2. Lizada C (1993) Mango. In: Biochemistry of fruit ripening. Seymour GB, Taylor JE, Tucker GA (eds) Chapman and Hall, London. pp 255-271.

3. Mitra SK, Baldwin EA (1997) Mango. In: S. Mitra (ed.). Postharvest physiology and storage of tropical and subtropical fruits. CAB International, Wallingford UK, pp. 85-122.

4. Subrahmanyam KV (1986) "Postharvest losses in Horticultural crops, An appraisal", Agricultural situation in india 41: 339-343.

5. Zuraida N (2003) Sweet Potato as an Alternative Food Supplement during Rice Shortage. Journal Litbang Pertanian 22: 150-155.

6. Gopalan C, Rama sastri BV, Balasubramanian SC (1989) Nutritive Value of Indian Foods. National Institute of Nutrition, Hyderabad, India.

7. Picha DH (1985) HPLC Determination of Sugars in Raw and Baked Sweet Potatoes. J food Sci 50: 1189-1190.

8. Valetudie JC, Gallant DJ, Bouchet B, Colonna P, Champ M (1999) Influence of Cooking Procedures on Structure and Biochemical Changes in Sweet Potato. Starch-Starke 51: 389-397.

9. Irwandi, Cheman YB (1996) Durian Leather: Development, Properties and Storage Stability. J Food Quality 29: 479-489.

10. Chen Z, Sagis L, Legger A, Linssen JPH, Schols HA, et al. (2002) Evaluation of Starch Noodles Made from Three Typical Chinese Sweet-potato Starches. J Food Sci 67: 3342-3347.

11. Maskan A, Kaya S, Maskan M (2002) Hot air and sun drying of grape leather (pestil). J Food Eng 54: 81-88.

12. Maskan $M$ (2001) Drying, shrinkage and rehydration characteristics of kiwifruits during hot air and microwave drying. J foodf Eng 48: 177-182.

13. Xuguang $\mathrm{H}$, Fu-Hung $\mathrm{H}$ (2006) Physical properties, sensory attributes, and consumer preference of Pear Fruit Leather. J Food Sci 70: E177-E186.

14. Forson FK, Agbeko KE, Edwin IA, Sunnu A, Brew-Hammond A, et al. (2004) Solar energy resource assessment for Ghana, Department of Mechanical Engineering, Kwame Nkrumah University of Science and Technology, Kumasi, Ghana.

15. Walter WM (1987) Effect of Curing on Sensory Properties and Carbohydrate Composition of Baked Sweet Potatoes. J Food Sci 52: 1026-1029.

16. Purcell AE, Walter WM (1988) Comparison of carbohydrate components in Sweetpotatoes baked by convection heating and microwave heating. J Agric Food Chem 36: 360-362

17. Sun H, Zhao P, Ge X, Xia Y, Hao Z, et al. (2010) Recent advances in microbial raw starch degrading enzymes. Appl Biochem Biotechnol 160: 988-1003.

18. AOAC (1990) Official methods of Analysis of the Association of Official Analytical Chemists. (4thEd. Williams, S). Association of Analytical Chemists, USA.

19. AOAC (2000) Official methods of analysis. 17th Ed. Association of Officia AnalyticalChemists (No. 967.21 Ascorbic acid in vitamin preparation and juice), Gaithersburg, MD, USA.

20. Nabubuya A, Namutebi A, Byaruhanga Y, Narvhus J, Stenstrøm Y, et al. (2012) Amylolytic Activity in Selected Sweetpotato (Ipomoea batatas Lam) Varieties during Development and in Storage. Food and Nutrition Sciences 3: 660-668.

21. Reemer FP (1990) Consumption patterns of sweetpotato in Southeast Asia User's Perspective with Agricultural Research and Development (UPWARD), Wageningen Agricultural University, Netherlands.
22. Hamann DD, Miller NC, Purcell EA (1980) Effects of curing on the flavor and texture of baked sweet potatoes. J Food Sci 45: 992-994

23. Alais C, Linden G (1991) Food Chemistry, Ellis Horwood series in food science and technology press. New York, USA.

24. Hoover R (2001) Composition, molecular structure and physicochemical properties of tuber and root starches: A review. Carb Polymers 45: 253-267.

25. Moorthy SN (2002) Physicochemical and functional properties of tropical tuber starches: A Review. Starch Starke 54: 559-592.

26. Zuidam NJ, Nedovic $\vee(2009)$ Classification of starch hydrolysates based on the $D E$ value encapsulation technologies for active food ingredients and food processing. p39.

27. Tharanathan RN (2002) Food-derived carbohydrates-structural complexity and functional diversity. Crit Rev Biotechnol 22: 65-84.

28. Leung HK (1986) Water activity and other colligative properties of foods. In: Physical and chemical properties of food, Okos MR, Michigan: American Society of Agriculture Engineers. pp 138-185.

29. Troller (1980) In: Ingredients in meat products: properties, functionality and applications. Rodrigo Tarté (ed) C.A Simpson and J.N Sofos Springer publication. pp. 332-333

30. Ekanayake S, Bandara L (2002) Development of banana fruit leather. Annals of the Sri Lanka Department of Agriculture 4: 353-358.

31. Jain PK, Nema PK (2007) Processing of pulp of various cultivars of guava (Psidium guajava I.) for leather production. Agric Eng Int: the CIGR Ejournal. 9: FP 07001.

32. Rao VS, Roy SK (1980) Studies on dehydration of mango pulp II Storage studies of mango sheets/leather. Indian Food Packer 34: 72-79.

33. Ashaye OA, Babalola SO, Babalola AO, Aina JO, Fasoyiro SB (2005) Chemical and Organoleptic Characterization of Pawpaw and Guava Leathers. World $J$ Agric Sci 1: 50-51

34. Kader AA (1999) Fruit maturity, ripening, and quality relationships. Department of Pomology, University of California, USA

35. Sánchez RRM, Graü RMA, Serrano IO, González-Aguilara GA, Martín-Belloso O (2009) Effect of minimal processing on bioactive compounds and antioxidan activity of fresh-cut 'kent' mango (Mangifera indica L.). Postharvest Biol Tec 51: $384-390$

36. Barbosa-Cánovas GV, Vega-Mercado H (1996) Dehydration of foods Chapman \& Hall, New York, USA

37. Okilya S, Mukisa IM, Kaaya AN (2010) Effect of solar drying on the quality and acceptability of jackfruit leather. Electr J Envir Agric Food chem 9: 101-111.

38. Rose IM, Vasanthakaalam H (2011) Comparison of the nutrient composition of four sweet potato varieties cultivated in Rwanda. Am J Food Nutr 1: 34-38.

39. Huang AS, Tanudjaja L, Lum D (1999) Content of alpha-, beta-carotene, and dietary fibre in 18 sweetpotato varieties grown in Hawaii. Journal of Food Composition and Analysis 12: 147-151. 